\title{
Aspek Insentif, Mekanisme Pengambilan Keputusan dan Koordinasi (Analisis Komparasi Sistem-Sistem Ekonomi)
}

\author{
Nafis Irkhami \\ Pascasarjana Ekonomi Syariah, IAIN Salatiga \\ nafis_ir@yahoo.com
}

\begin{abstract}
This paper is intended as a general comparative study on the economic system of capitalism, socialism and Islamic economics. The comparative analysis is conducted by reviewing aspects of incentives, decision-making mechanism and coordination. Inter-systemic review in this paper shows that Islamic economic system is determined by the parameters of its own ethical system which shows originality and relativity. Unlike other systems, the ethical impulse that is based on the Islamic worldview is fully integrated with Islamic economic motives. Limited freedom assigned to the behavior of consumption and production, as well as the emphasis on the distribution of wealth cannot be separated from the purpose of goodness (world and the hereafter).
\end{abstract}

Keywords: Islamic economic system, aspects of incentives, decisionmaking, coordination

\begin{abstract}
Abstrak
Tulisan ini dimaksudkan sebagai studi komparasi general atas sistem ekonomi kapitalisme, sosialisme (ekonomi komando) dan ekonomi Islam. Analisis komparasi tersebut dilakukan dengan meninjau aspe-aspek insentif, mekanisme pengambilan keputusan dan koordinasi. Tinjauan inter-sistemik dalam tulisan ini menunjukkan bahwa sistem ekonomi Islam ditentukan berdasarkan parameter-parameter sistem etisnya sendiri, yang menunjukkan adanya orisinalitas dan relativitasnya. Tidak seperti sistem lain, impuls-impuls etik yang didasarkan pada worldview Islam tersebut sepenuhnya terintegrasi dengan motif-motif ekonomi Islam. Kebebasan terbatas yang ditetapkan untuk perilaku konsumsi dan produksi, serta penekanan pada distribusi kekayaan tidak dapat dipisahkan dari tujuan kemaslahatan (dunia maupun akhirat).
\end{abstract}

Kata kunci: Sistem ekonomi Islam, aspek insentif, pengembilan keputusan, koordinasi 


\section{Pendahuluan}

Pada dasarnya sistem adalah suatu "organisasi besar" yang menjalin beberapa subyek (atau obyek) serta perangkat kelembagaan dalam suatu tatanan tertentu. Subyek atau obyek pembentuk sebuah sistem dapat berupa orang-orang atau masyarakat untuk sebuah sistem sosial atau sistem kemasyarakatan; makhluk-makhluk hidup dan benda alam untuk suatu sistem kehidupan atau sistem lingkungan; barang atau alat untuk suatu sistem peralatan; data, catatan, atau kumpulan fakta, untuk suatu sistem informasi; atau bahkan kombinasi dari subyek-obyek tersebut. Lebih jauh, sistem juga dapat dimaksudkan sebagai (1) seperangkat unsur yang secara teratur saling berkaitan sehingga membentuk suatu totalitas, (2) suatu kesatuan yang terpadu secara holistik, di dalamnya terdiri dari bagian-bagian dan masingmasing bagian memiliki ciri dan batas tersendiri. Masing-masing bagian itu memiliki keterkaitan yang saling mendukung dalam sistem yang holistik tersebut.

Dengan demikian, sistem ekonomi dapat diartikan sebagai suatu sistem yang mengatur serta menjalin hubungan ekonomi antar manusia dengan seperangkat kelembagaan dalam suatu tatanan kehidupan. Sebuah sistem ekonomi terdiri atas unsur-unsur manusia sebagai subyek; barangbarang ekonomi sebagai obyek, serta seperangkat kelembagaan yang mengatur dan menjalinnya dalam kegiatan berekonomi. Perangkat kelembagaan dimaksud meliputi lembaga-lembaga ekonomi (formal maupun non formal); cara kerja; mekanisme hubungan; hukum dan peraturan-peraturan perekonomian; serta kaidah dan norma-norma lain (tertulis maupun tidak tertulis); yang dipilih atau diterima, ditetapkan oleh masyarakat di tempat tatanan kehidupan berlangsung. Jadi dalam perangkat kelembagaan ini termasuk juga kebiasaan, perilaku, dan etika masyarakat; sebagaimana mereka terapkan dalam berbagai aktivitas yang berkenaan dengan pemanfaatan sumberdaya bagi pemenuhan kebutuhan.

Sistem ekonomi juga dapat diartikan sebagai keseluruhan lembaga ekonomi yang dilaksanakan atau dipergunakan oleh suatu bangsa atau negeri dalam mencapai cita-cita yang telah ditetapkan, di mana pengertian lembaga atau institusi ekonomi adalah pedoman, aturan atau kaidah yang digunakan seseorang atau masyarakat dalam melakukan kegiatan ekonominya, yaitu 
dalam melakukan produksi, distribusi dan atau konsumsi terhadap barang dan jasa.

Berdasarkan pengertian-pengertian tersebut maka yang membedakan antara sistem ekonomi suatu negara dengan sistem ekonomi negara lain adalah faktor-faktor meta ekonomis seperti pandangan hidup suatu bangsa, nilai-nilai yang dijunjung tinggi, kebudayaan suatu bangsa atau masyarakat. Suatu sistem ekonomi tidaklah berdiri sendiri. Ia berkaitan dengan falsafah, worldview dan pola hidup masyarakat tempatnya berpijak. Sebuah sistem ekonomi sesungguhnya merupakan salah satu unsur saja dalam suatu suprasistem kehidupan masyarakat. Ia merupakan bagian dari kesatuan ideologi kehidupan bermasyarakat di suatu negara. Oleh karenanya, bukanlah hal yang mengherankan apabila dalam perjalanan atau penerapan suatu sistem ekonomi tertentu di sebuah negara terjadi benturan, konflik atau bahkan tantangan. Pelaksanaan suatu sistem ekonomi tertentu di sebuah negara akan berjalan mulus jika lingkungan kelembagaan masyarakatnya mendukung.

Tulisan ini berupaya untuk memberikan tinjauan umum beberapa sistem ekonomi dunia. Uraian berikut lebih dimaksudkan sebagai komparasi general atas sistem ekonomi kapitalisme, sosialisme (ekonomi komando) dan ekonomi Islam.

\section{Kapitalisme: Kebebasan dan Individualisme Ekonomi}

Adam Smith (1723-1790) adalah salah satu tokoh ekonomi-politik yang selalu dikaitkan dengan Kapitalisme. Melalui dua karya monumentalnya, yaitu The Theory of Moral Sentiments (1759) dan An Inquiry into the Nature and Causes of the Wealth Nations (1776), ia berhasil membidani teori ekonomi baru. Buku kedua mengawali kajian sistematis tentang pembangunan industri dan perdagangan di Eropa. Ekonom ini meyakini bahwa self-interest rationality dan kompetisi dapat menghasilkan kesejahteraan manusia. Gagasan Smith merupakan embrio bagi lahirnya berbagai disiplin ilmu ekonomi yang terkait dengan perdagangan bebas, kapitalisme dan liberalisme ekonomi, yang sekarang sedang menguasai aspek politik-ekonomi dunia.

Kapitalisme merepresentasikan sebuah sistem ekonomi dan sosial sekaligus di mana alat-alat produksi kepemilikannya didominasi secara 
individual. Investasi, distribusi, produksi, tingkat pendapatan, penentuan tingkat harga barang dan jasa ditentukan melalui sebuah mekanisme pasar. Pada dasarnya konsep kapitalisme selalu berkembang setiap saat sesuai dengan bangunan analisis kontemporer. Komponen-komponen konsep yang digunakan untuk mendefinisikan kapitalisme selalu berkembang mengikuti perubahan teori dan prakteknya di lapangan.

Kapitalisme merupakan sistem sosial yang menyeluruh, lebih dari sekedar sistem perekonomian. Kapitalisme tidak dapat dilepaskan dari gerakan individualism (Ebenstein, 1990: 72). Hal ini sejalan dengan pernyataan Rand (1970: 6) bahwa kapitalisme adalah "a social system based on the recognition of individual rights, including property rights, in which all property is privately owned."

Epistemologi sistem ekonomi Kapitalisme adalah positivistik. Dengan demikian, faham materialistik sangat dominan dalam sistem kapitalis. Sesuatu dapat dikatakan benar dan bernilai sahih apabila dapat dibuktikan secara inderawi yang sifatnya adalah materi. Faham ini kemudian berujung pada tereliminasinya unsur nilai dari sistem ekonomi Kapitalis.

Laissez-faire merupakan terma yang tidak dapat dilepaskan dari diskursus Kapitalisme. Menurut "hikayat" sejarah, istilah tersebut muncul pada tahun 1680. Ketika itu Menteri Keuangan Perancis, Jean Baptiste Colbert mengadakan pertemuan dengan beberapa pengusaha kelas kakap yang dipimpin oleh M. Le Gendre. Ketika para pengusaha tersebut ditanya 'apa yang bisa dilakukan oleh Pemerintah Prancis untuk membantu dunia usaha', mereka kemudian menjawab secara singkat Laissez-nous Faire. Istilah ini diterjemahkan dalam bahasa Inggris dengan leave me alone atau leave us be, sedangkan dalam Bahasa Arab diterjemahkan menjadiÏÚå íUãá .

Dalam pandangan laissez-faire, pemerintah tidak mempunyai kewajiban dan tanggung jawab untuk melakukan intervensi guna menjaga distribusi dan pemerataan kesejahteraan, sehingga masyarakat dapat terbebas dari kemiskinan dan kesengsaraan. Ungkapan lain yang juga populer dalam sistem ekonomi Kapitalisme adalah bahwa good government is less govern. Ungkapan tersebut menunjukkan bahwa pemerintah tidak perlu banyak melakukan campur-tangan bidang ekonomi karena sebagian besar akan diatur oleh mekanisme pasar (Rand, 1970: 24). Pengertian ini kemudian menjadikan 
Kapitalisme sebagai sebuah sistem ekonomi pasar.

The New Dictionary of Cultural Literacy (2002) mendefinisikan ekonomi pasar sebagai sebuah sistem ekonomi di mana produksi dan konsumsi barang-jasa ditentukan melalui mekanisme pasar bebas. Dalam ekonomi pasar, produsen dan konsumen akan menemukan sendiri ritme mereka tentang apa yang akan mereka beli dan apa yang akan mereka produksi. Keputusan mereka dipengaruhi oleh tingkat permintaan, penawaran dan tekanan kompetisi antar pelaku pasar. Mekanisme pengambilan keputusan dalam sistem kapitalisme ditentukan sendiri oleh pelaku pasar, yaitu produsen dan konsumen. Alur pengambilan keputusan ini dengan demikian menggunakan sistem bottom-up, artinya bahwa keputusan ekonomi tidak terpusat di tangan pemerintah.

Menurut Smith, ketika individu digerakkan oleh self-interest untuk memenuhi kebutuhan pribadinya, maka dengan sendirinya individu-individu tersebut akan memenuhi kebutuhan sosial mereka. Mekanisme invisible hand juga berperan secara otomatis dalam menstabilkan tingkat permintaan dan penawaran Stiglitz, seorang pemenang nobel ekonomi, mengkritik, "the reason that the invisible hand often seems invisible is that it is often not there."

Lerner (1988) menyebutkan bahwa revolusi komersial dan industri pada dunia modern awal dipengaruhi oleh asumsi-asumsi kapitalisme dan merkantilisme. Kapitalisme adalah sebuah sistem yang didisain untuk mendorong ekspansi komersial melewati batas-batas lokal menuju skala nasional dan internasional. Pengusaha kapitalis mempelajari pola-pola perdagangan internasional, di mana pasar berada dan bagamana memanipulasi pasar untuk keuntungan mereka. Penjelasan Robert Learner ini paralel dengan tudingan Karl Marx bahwa imperialisme adalah kepanjangan tangan dari kapitalisme.

Sistem kapitalisme mulai berkembang di Inggris pada abad $18 \mathrm{M}$ dan kemudian menyebar luas ke kawasan Eropa Barat laut dan Amerika Utara. Risalah terkenal Adam Smith, yaitu The Wealth of Nations, yang mengekspresikan gagasan "laissez faire" dalam ekonomi, bertentangan sekali dengan merkantilisme yaitu adanya intervensi pemerintah dalam urusan negara. Smith berpendapat bahwa jalan terbaik untuk memperoleh kemakmuran adalah dengan membiarkan setiap individu mengejar 
kepentingan-kepentingan mereka sendiri tanpa keterlibatan negara (Lerner, 1988).

Munculnya kerajaan-kerajaan industri pada awal abad 20 cenderung menciptakan konsentrasi pemilikan saham oleh segelintir individu kapitalis. Ini memaksa pemerintah (Barat) mengintervensi mekanisme pasar melalui kebijakan-kebijakan seperti undang-undang anti-monopoli, sistem perpajakan, dan jaminan kesejahteraan. Fenomena intervensi negara terhadap sistem pasar dan meningkatnya tanggungjawab pemerintah dalam masalah kesejahteraan sosial dan ekonomi merupakan indikasi terjadinya transformasi kapitalisme. Transformasi ini, menurut Ebenstein, dilakukan agar kapitalisme dapat menyesuaikan diri dengan berbagai perubahan ekonomi dan sosial. Lahirlah konsep negara kemakmuran (welfare state) yang oleh Ebenstein disebut sebagai "perekonomian campuran" (mixed economy) yang mengkombinasikan inisiatif dan milik swasta dengan tanggungjawab negara untuk kemakmuran sosial.

Habermas memandang transformasi itu sebagai peralihan dari kapitalisme liberal kepada kapitalisme lanjut (late capitalism, organized capitalism, advanced capitalism). Selanjutnya Habermas menyebutkan bahwa state regulated capitalism (nama lain kapitalisme lanjut) mengacu kepada dua fenomena: (a) terjadinya proses konsentrasi ekonomi seperti korporasikorporasi nasional dan internasional yang menciptakan struktur pasar oligopolistik, dan (b) intervensi negara dalam pasar. Untuk melegitimasi intervensi negara yang secara esensial kontradiktif dengan kapitalisme liberal, maka menurut Habermas, dilakukan repolitisasi massa, sebagai kebalikan dari depolitisasi massa dalam masyarakat kapitalis liberal. Upaya ini terwujud dalam sistem demokrasi formal.

Satu hal menarik yang perlu dicermati dari tesis Weber dalam bukunya yang sangat populer, The Protestant Ethic and the Spirit of Capitalism (judul aslinya adalah Die Protestantische Ethik Und Der Geist Des Kapitalismus) adalah pernyataannya bahwa Kapitalisme berkembang di saat kaum Protestan, terutama Kalvinis, mempengaruhi sebagian besar umatnya untuk bekerja dalam perspektif sekuler, mengembangkan dunia bisnis dan memperbanyak kekayaan untuk investasi. Dengan kata lain, etika Protestan merupakan sebuah kekuatan di balik 'aksi masa' untuk membangun dan mengembangkan Kapitalisme. 


\section{Keunggulan Kapitalisme}

Sebagai sebuah "peradaban", usia Kapitalisme memang belumlah lama. Proses maturasi dan koreksi dalam perjalanannya selalu terjadi. Hal inilah yang kemudian menjadi salah satu alasan mengapa Kapitalisme mempunyai usia yang lebih lama jika dibanding dengan Sosialisme, Komunisme maupun Fasis.

Di antara kekuatan Kapitalisme adalah daya adaptasi dan transformasi Kapitalisme yang sangat tinggi, sehingga ia mampu menyerap dan memodifikasi setiap kritik dan rintangan untuk memperkuat eksistensinya. Sebagai contoh, bagaimana ancaman pemberontakan kaum buruh yang diramalkan Marx tidak terwujud, karena di satu sisi, kaum buruh mengalami pembekuan kesadaran kritis (reifikasi), dan di lain sisi, kelas borjuasi kapital melalui negara memberikan "kebaikan hati" kepada kaum buruh dengan konsep "welfare state". Pada gilirannya, kaum kapitalis memperoleh persetujuan (consent) untuk mendominasi masyarakat melalui apa yang disebut Gramsci sebagai hegemoni ekonomi, politik, budaya; atau seperti yang disebutkan Heilbroner bahwa rezim kapital memiliki kemampuan untuk memperoleh kepatuhan massa dengan memunculkan "patriotisme" ekonomik.

Kapitalisme yang memberikan kebebasan berkreasi yang nyaris tanpa batas, banyak melahirkan inovasi dan temuan-temuan teknologi yang menakjubkan. Tidak jarang, kreasi manusia masuk dalam wilayah yang mungkin masih dalam batas-batas imajinasi. Namun karena kompetisi dan free fight dalam percaturan ekonomi yang sangat ketat, batas-batas imajinasi dapat ditembus untuk menghasilkan sebuah produk dengan nilai ekonomi tinggi. Menurut Friedman, motif mencari keuntungan adalah yang membangun kehidupan Kapitalis menjadi lebih dinamis (Friedman, 1972: 133).

Dengan penuh optimisme Bernard Murchland (1992: 82) menaruh harapan bahwa kapitalisme demokratis adalah humanisme yang dapat menyelamatkan peradaban manusia di masa depan. Kreativitas budaya kapitalisme mampu menyerap ide-ide serta toleransi terhadap berbagai pemikiran. Kebebasan dan hak individu memberi ruang gerak manusia dalam berinovasi dan berkarya demi tercapainya keberlangsungan hidup dan kebahagiaan. Kebebasan merupakan faktor yang menjadikan Kapitalisme menjadi sistem yang tetap eksis jika dibandingkan Sosialisme. 


\section{Kelemahan Kapitalisme}

Asumsi yang dianut kapitalisme adalah pandangan reduksionis satu dimensi manusia yang berasal dari rasionalisme. Studi psikologi menunjukkan bahwa perilaku manusia tidak semata-mata didorong oleh kesadaran atau rasionalitas, melainkan juga banyak dipengaruhi oleh ketidaksadaran dan irasionalitas. Asumsi kapitalisme meyakini bahwa distribusi kekayaan akan terjadi dengan sendirinya bila masyarakat telah makmur. Teori ini melupakan aspek irasionalitas manusia yang serakah dan keji. Dorongan yang tidak pernah puas untuk menumpuk kapital merupakan bentuk patologis megalomania dan narsisisme.

Mekanisme pasar yang diandalkan Kapitalisme nampaknya harus banyak dikoreksi. Intervensi pemerintah melalui serangkaian regulasi untuk "menyempurnakan pasar" tetap saja melahirkan penyimpangan dan penyakit ekonomi. Terpusatnya kesejahteraan pada sekelompok kecil masyarakat, pertumbuhan ekonomi yang tidak diikuti dengan pemerataan dan distribusi, perilaku monopoli, monopsoni dan beberapa perilaku negatif lainnya merupakan sekian kecil contoh dari serangkaian kegagalan mekanisme pasar. Sejak 1994-1998, nilai kekayaan bersih 200 orang terkaya di dunia bertambah dari 40 miliar dolar AS menjadi lebih dari 1 trilun dolar AS; aset tiga orang terkaya di dunia lebih besar dari GNP 48 negara terbelakang; 1/5 orang terkaya di dunia mengkonsumsi $86 \%$ semua barang dan jasa; $1 / 5$ orang termiskin dunia hanya mengkonsumsi kurang dari 1\% saja (The United Nations Human Development Report, 1999).

Pandangan epistemologi Kapitalisme adalah positivistik-mekanistik. Hal ini berimplikasi terpisahkannya fakta dengan nilai, hanya terfokus pada apa yang disebut dengan fenomena fenomena fakta dan mengabaikan nilai. Salah satu indikatornya adalah ketidakmampuannya menjelaskan perkembangan sains modern dan kritikan dari fenomenologi hermeneutik (human sciences). Pola pikir positivistik hanya satu dimensi, yaitu dialektika positif, yang pada gilirannya mereduksi kemampuan refleksi kritis manusia untuk menari makna-makna tersembunyi di balik fenomena-fenomena.

Darwinisme sosial juga sering dikaitkan dengan Kapitalisme sesuai dengan teori Survival of the fittest-nya. Robert Wright (1994: 7) menyatakan: 
"Tidak dapat dipungkiri, teori evolusi memiliki sejarah panjang yang kelam dalam penerapannya pada hubungan antar manusia. Setelah bercampur dengan filsafat politik di sekitar peralihan abad ini, untuk membentuk ideologi yang tidak jelas, yang dikenal dengan "Darwinisme Sosial", ideologi ini digunakan oleh kaum rasis, fasis dan kapitalis yang tidak memiliki hati nurani."

Menurut Darwiniwme Sosial, tatanan masyarakat terbentuk dari prinsip bahwa yang kuat akan tetap bertahan hidup. Pemberian bantuan dan pemberdayaan bagi masyarakat lemah dan menjadikan mereka tetap bertahan hidup adalah pelanggaran terhadap prinsip ini. Yang kaya tetap kaya dikarenakan mereka lebih mampu bertahan hidup; sebagian bangsa menjajah bangsa lain, sebab bangsa-bangsa penjajah ini lebih cerdas dan unggul. Spencer bersiteguh menerapkan doktrin ini:

"Jika mereka benar-benar layak untuk hidup, mereka akan hidup, dan sudah sebaiknya jika mereka harus hidup. Jika mereka benarbenar layak untuk mati, mereka akan mati, dan adalah paling baik jika mereka harus mati."

Karena kegagalan kapitalisme itulah, maka sejak awal, Joseph Schumpeter meragukan kapitalisme. Dalam konteks ini ia mempertanyakan, "Can Capitalism Survive"? No, I do not think it can. Selanjutnya ia mengatakan, "Capitalism would fade away with a resign shrug of the shoulders". Sejalan dengan pandangan di atas, pakar ekonomi Fritjop Chapra dalam bukunya, The Turning Point, Science, Society and The Rising Culture (1999) dan Ervin Laszio dalam buku 3rd Millenium, The Challenge and The Vision (1999), mengungkapkan bahwa ekonomi konvensional (kapitalisme) yang berlandaskan sistem ribawi, memiliki kelemahan dan kekeliruan yang besar dalam sejumlah premisnya, terutama rasionalitas ekonomi yang telah mengabaikan moral. Kelemahan itulah menyebabkan ekonomi (konvensional) tidak berhasil menciptakan keadilan ekonomi dan kesejahteraan bagi umat manusia.

\section{Ekonomi komando}

Encyclopedia Britannica (2007) mendefinisikan "Command Economy" sebagai sistem ekonomi di mana negara atau pemerintah mengelola 
ekonomi. Kata ekonomi komando ini berasal dari bahasa Jerman "Befehlswirtschaft." Istilah lain yang banyk digunakan untuk menyebutnya adalah ekonomi terencana (planned economy) centrally planned economy (Barth dan Caprio, 2007; Bouman dan Brand, 1997: 91).

Dalam ekonomi komando pemerintah atau negara mengontrol semua aktvitas ekonomi dan membuat keputusan ekonomi dan distribusi pendapatan (Myers, 2004: 288). Pemerintah memutuskan apa yang akan diproduksi dan menunjuk perusahaan atau lembaga yang akan memproduksi barang dan jasa itu (Ollman, 1997: 12). Tentu saja ekonomi komando ini sangat berlawanan dengan system ekonomi pasar, di mana produksi, distribusi dan harga diputuskan oleh pemilik faktor produksi bukan oleh negara.

Ada tiga pilar utama ekononomi komando (Microsoft Encarta, 2008):

1. Pemerintah memiliki semua alat produksi, pertanian, pabrik, laboratorium, toko dan sebagainya, dan dikelola oleh tenaga (manajer) yang dipekerjakan oleh negara.

2. Kontrol atas manajer tersebut, dilakukan oleh perencana ekonomi party yang kemudian menetapkan target output dan harga termsuk juga melakukan intervensi terhadap semua keputusan perusahaan seperti produk mix dan skedul produksi.

3. Adanya kebijakan atas industri yang akan dijadikan prioritas investasi (di Uni Soviet, Korea Utara biasanya industri militer) dibandingkan dengan dengan investasi terhadap produksi barang konsumsi dan makanan.

Namun demikian dalam ekonomi komando bisa saja terdapat perusahaan milik negara, perusahaan swasta yang diarahkan negara, atau kombinasi keduanya.

Ekonomi terencana dan ekonomi komando walaupun dianggap sinonim namun ada beberapa perbedaan, seperti dalam ekonomi komando, produksi dimiliki oleh publik. Sedangkan ekonomi terencana merupakan system ekonomi dimana pemerintah mengontrol dan mengatur produksi, distribusi, harga dsb namun dalam ekonomi komando selain sama-sama memiliki regulasi, biasanya ada kepemilikan publik dalam industri. Oleh karena itu ekonomi komando adalah ekonomi terencana namun tidak sebaliknya (sebagai contoh: Nazi jerman merupakan ekonomi terencana namun Uni 
Soviet adalah bentuk ekonomi komando).

Sejak tahun 1980an dan 1990an, banyak negera yang menganut sistem ekonomi komando melakukan deregulasi. Mereka beralih ke ekonomi pasar dengan memperbolehkan sektor privat untuk membuat keputusan tentang harga, produksi dan keputusan distrbusi. Namun ekonomi komando ini masih berjalan di beberapa negera seperti Kuba, Korea Utara dan Myanmar (Brabant, 1991: 16).

Secara konseptual, dengan ekonomi komando dapat menjamin pemanfaatan sumber daya yang tersedia secara terus menerus. Dibawah ekonomi komando, maka tingkat pengangguran dan kapasitas idle produksi berada pada level yang paling rendah, dan ekonomi dapat berkembang secara stabil tidak terhalangi oleh resesi maupun inflasi Investasi infrastruktur jangka panjang dapat dilakukan tanpa takut market downturn ataupun pembatalan proyek, terutama proyek-proyek yang beresiko tinggi (seperti reaktor nuklir) atapun proyek untuk kepentingan publik (seperti sekolah).

Jika ekonomi pasar bertujuan memaksimalkan kesejahteraan melalui evolusi, maka ekonomi komando lebih kepada designnya. Sementara evolusi cenderung untuk mencapai lokal maksimum dalam kesejahteran secara agregat, sedangkan design secara teori adalah kemampuan untuk mencapai global maksimum. Sebagai contoh, kota yang terencana dapat didesign agar memiliki sistem tranportasi yang effisien, sedangkan kota yang tumbuh dan berkembang secara apa adanya cenderung menjadi kota dengan transportasi semrawut.

\section{Mencapai tujuan kolektif melalui pengorbanan individu}

Ekonomi komando lebih "melayani" kepentingan kolektif dibanding kepentingan individu. Menurut sistem ekonomi ini upah didistribusikan negara berdasarkan jumlah yang dianggap negara sesuai dengan kinerjanya. Ekonomi komando meminimalkan motif individu atas profit (sebagai fungsi penekan proses produksi) dan meletakkan upah (profit) tadi ditangan negara sebagai perencana untuk menentukan produksi barang atau jasa yang tepat.

Negera dapat menggunakan tanah, tenaga kerja dan modal untuk mencapai tujuan ekonomi negera. Permintaan konsumen dapat dihambat melalui investasi modal untuk pembangunan ekonomi. Negara dapat mem- 
bangun industri besar dalam situasi ekonomi yang sulit tanpa perlu menunggu beberapa tahun agar modal terkumpul melalui ekpansi industri kecil dan tanpa perlu pembiayaan dari luar. Itulah yang terjadi di Uni Soviet selama tahun 1930an ketika pemerintah menekan GNP untuk konsumsi privat dari $80 \%$ menjadi $50 \%$. Walaupun ada penurunan kualitas hidup secara individual tetapi pemerintah berhasil mencapai tujuan ekonominya.

\section{Ineffisiensi distribusi dalam sistem ekonomi Komando}

Para kritikus berpendapat bahwa dalam ekonomi komando, perencana (pemerintah) tidak dapat mengetahui preferensi konsumen, surplus ataupun kekurangannya dan oleh karena itu tidak dapat secara effisien mengkoordinasikan produksi (dalam ekonomi pasar, system free price digunakan sebagai instrumennya). Sebagai contoh selama beberapa saat dalam sejarah Uni Soviet, kelangkaan sempat terjadi sehingga penduduk harus antri beberapa jam untuk membeli kebutuhan pokok. Kelangkaan ini terjadi karena pemerintah memutuskan bahwa pada saat itu membuat traktor lebih penting daripada membuat roti misalnya, atau bisa juga karena pemerintah tidak memberi supply gandum yang cukup kepada pabrik roti atau pemerintah tidak memberi insentif kepada pabrik roti agar memproduksi roti sesuai dengan yang dbuthkan dngan kualitas yang sudah ditentukan. Kesulitan ini pertama kali dikemukan oleh ekonom Ludwig von Mises, yang menyebutnya dengan istilah "economic calculation problem". Sedangkan ekonomi Janos Kornai mengembangkannya menjadi teori ekonomi kelangkan (shortge economic theory) dimana para pendukungnya berpendapat bahwa kelangkaan tidak disebabkan oleh kurangnya suply.

Namun disatu sisi, pada ekonomi komando jga terdapat masalah ketika surplus. Surplus mengindikasikan bahwa adanya pemborosan tenaga kerja dan material yang tidak dapat dimanfaatkan untuk memenuhi kebutuhan masyarakat. Kritikus mengatakan bahwa ekonomi pasar mencegah surplus jangka panjang karena beroperasinya penawaran dan permintaan menyebabkan harga turun jika suply lebih besar dari demand, yang berarti produsen harus menghentikan produksi atau akan mengalami kerugian. Disini "invisible hand" mencegah dari apa yang disebut surplus ataupun kelangkaan dan menyediakan effisiensi maksimum dalam memenuhi kebutuhan 
konsumen. Kritikus juga berpendapat bahwa walaupun dalam ekonomi komando harga tidak dapat mengambang secara bebas,

Namun dsna tidak ada mekanisme yang akurat yang dapat mengetahui barang apa yang hars diproduksi secara besar-besaran dan barang apa yang harus diproduksi dalam jumlah yang terbatas. Menurut mereka effisiensi hanya dapat diperoleh melalui mekanisme pasar, dimana produsen dapat membuat keputusan produksi berdasar motif profit masingmasing.

Salah satu kritik lain dari ekonomi komando adalah sulitnya untuk mengengedepankan invasi dibanding dengan ekonomi pasar. Dalam ekonomi pasar, penemu dapat meraup banyak uang melalui paten, artinya lebih banyak insentifuntuk inovasi dalam ekonomi pasar. Sebaliknya ekonomi komando dapat mengerahkanseluruh sumber daya nasional untuk riset dan pengembangan, jika dirasa terdapat hal yang penting untuk kepentingan nasionalnya, biasanya teknologi militer. Uni Soviet mampu mempertahankan kompetisinya dengan Amerika Serikat selama perang dingin meskipun kemampuan ekonominya lebih kecil.

Ketika upah dan harga ditentukan oleh pemerintah secara terpusat, maka disana tidak terdapat insentif atau penghargaan kepada orang yang memiliki kinerja lebih baik dbanding yang lain. Tentu insentifnya adalah dengan bekerja sesedikit mungkin. Dalam situasi seperti itu maka produktivitas secara umuma adalah rendah.

\section{Pelanggaran atas kebebasan pribadi}

Struktur top-down dalam ekonomi komando mendikte sebuah kultur operasi yang hegemoni, dimana dalam eknomi pasar terdapat beberapa model operasi yang bersama-sama bersaing seperti organisme dalam sebuah ekosistem. Pemerintah juga melakukan intervensi yang besar terhadap kehidupan pribadi seseorang. Misalnya saja, jika negara mengarahkan semua pekerjanya maka karir seseorang akan lebih terbatas. Jika barang dialokasikan oleh negara bukan oeh pasar, penduduk tidak dapat pindah ke dari satu tempat ke tempat lain tanpa mendapat ijin dari negara karena mereka tidak akan mendapat makanan dan rumah tinggal di tempat yang baru, karena sumber dayanya belum direncanakan. 
Karena negara mengontrol semua pilihan-pilihan individual, dan bersifat top down maka akan menjadi negara diktator dimana politisi dan birokrat memanfaatkan negara untuk mencapai tujuan mereka sendiri yang di jelaskan sebagai tujuan negara.

Ekonomi komando menciptakan kondisi sosial yang mendukung korupsi, dan pada umumnya pemerintah negara dengan sstem ekonomi ini adalah korup. Hal ini disebabkan oleh : pertama, pembuatan keputusan yang terpusat cederung terjadi penyalah gunaan kekuasaan. Kedua, model perencanaan yang ineffisien maka akan menimbulkan informasi yang tidak effisien yang kemudian cenderung untuk mem- bypas proses pengambilan keputusan resmi.

\section{Ekonomi Islam sebagai Sistem Alternatif}

Khurshid Ahmad (1997: 1) pernah melontarkan pertanyaan mendasar dan menarik tentang bagaimana membangun perekonomian negara-negara Muslim yang menyelaraskan nilai-nilai ekonomi, politik dan ideologinya yang khas? Apakah masyarakat muslim bisa membangun perekonomian dengan mengikuti sistem kapitalis, sosialis maupun derivasinya, dengan sedikit maupun banyak ketergantungan? Apakah perlu dilakukan rekonstruksi sosial-ekonomi secara total dengan asumsi, gagasan dan pola yang unik dan bernilai khusus untuk pembangunan dalam masyarakat muslim?

Pertanyaan-pertanyaan Khursid Ahmad tersebut tentu berangkat dari realitas yang terjadi dan melingkupi negeri-negeri muslim. Di mana hampir sebagian besarnya memiliki sumber daya yang luar biasa, tetapi keadaan ekonominya tetap tak berkembang, standar hidup rakyatnya masih rendah, dan bahkan cenderung hidup dalam keadaan subsisten. Mengalami ketimpangan dalam distribusi kekayaan, ketidakseimbangan dalam wilayah geografis, kesenjangan antara sektor ekonomi dan sosial, juga terjadi ketimpangan antara pusat industri dan daerah pertanian. Selain itu juga mengalami ketergantungan yang luar biasa sebagai pengaruh berkepanjangan dari warisan hubungan ekonomi kolonial sebagai prototipe pola hubungan "pusatpinggiran" (centre-periphery relationship).

Dunia Islam mengalami paradoks, ketika mengunakan prototipe pertumbuhan sebagai pola pembangunan yang dirancang pakar dan praktisi 
Barat yang kemudian "dijual" kepada perencana negara muslim melalui diplomasi internasional, tekanan ekonomi, infiltrasi intelektual dan cara lainnya. Dari berbagai kajian evaluasi kebijakan pembangunan dan kinerja ekonomi negara-negara muslim menunjukkan bahwa strategi imitasi gagal untuk menghasilkan kesejahteraan. Semua bukti menunjukkan bahwa usaha pembangunan selama ini masih lepas dari nafas Islami.

Pemecahan atas persoalan pelik yang dihadapi negeri-negeri muslim tersebut harus dimulai dengan peletakan kerangka befikir. Dengan kata lain, kerangka berfikir mestinya menjadi dasar untuk menjawab persoalanpersoalan diatas. Dalam kerangka berfikir tersebut harus dicanangkan sebuah premis baru bahwa pembangunan sistem ekonomi dalam kerangka ajaran Islam dan ilmu ekonomi pembangunan Islami berakar pada kerangka nilai yang ada dalam al-Qur'an dan as-Sunah. Al-Qur'an dan As-Sunah merupakan titik rujukan kita yang paling mendasar. Premis kedua dalam pendekatan ini menolak sikap imitatif. Model kapitalis maupun sosialis serta derivasinya bukan merupakan ideal type, kendatipun kita juga dapat mengumpulkan sumber-sumber yang bermanfaat untuk diadaptasikan atau diintegrasikan dalam kerangka Islam tanpa harus mengurangi nilai-nilai normatif yang ada.

Ide sentral yang membatasi sistem ekonomi Islam, dan yang menempatkannya berbeda dengan sistem-sistem lainnya adalah desakannya untuk memasukkan secara eksplisit nilai-nilai etika yang didasarkan pada agama dalam suatu framework analisis yang terpadu. Ini dapat dipahami dari berbagai definisi ilmu ekonomi Islam yang dikemukakan oleh para ekonom muslim. Umar Chapra (1996: 33) misalnya, mendefinsikannya sebagai ekonomi dengan perspektif Islam. Ia menyatakan:

"Islamic economics may be defined as a branch of knowledge which helps realize human well-being through an allocation and distribution of scarce resources that is in conformity with Islamic teachings..."

Definsi serupa dikemukakan oleh M. A. Mannan (1986: 18), "Islamic economics is a social science which studies the economic problems of people imbued with the values of Islam." Khurshid Ahmad juga mengemukakan definisi ekonomi Islam yang tidak jauh berbeda, "a systematic effort to understand the economic problem and man's behavior in relation to that 
problem from an Islamic perspective." Definisi yang lebih praktis dinyatakan oleh Nejatullah Siddiqi, "Islamic economics is "the Muslim thinkers" response to the economic challenges of their time." Secara lebih tegas Naqvi (1981: 18) menyatakan bahwa perbedaan ekonomi Islam dengan konvensional adalah internalisasi nilai-nilai etika (agama) dalam ekonomi Islam.

Batasan-batasan yang telah dikemukakan di atas mengisyaratkan bahwa secara garis besar, ekonomi Islam dibedakan dari ekonomi konvensional dengan adanya pelekatan sudut pandang (worldview) Islam (Naqvi, 1981). Meskipun istilah yang digunakan seringkali berbeda, seperti worldview, way of life, values, visions, perspectives dan sebagainya, namun seluruhnya memiliki pengertian yang tidak jauh berbeda, yaitu sebagai suatu pandangan hidup. Beberapa definisi ekonomi Islam di atas juga mengisyaratkan bahwa paradigma ekonomi konvensional akan tetap berfungsi dalam membentuk paradigma ekonomi Islam secara praksis. Dengan kata lain, teori-teori ekonomi konvensional akan tetap menjadi diskursus ekonomi Islam.

Sistem perekonomian yang dikembangkan di Barat (negara-negara kapitalis, sosialis dan penganut derivasinya) banyak dipengaruhi oleh karakteristik unik, masalah spesifik, nilai eksplisit dan implisit serta infrastruktur sosial-politik-ekonomi yang khas dari kazanah peradabannya (Ahmad, 1997: 7-8). Hal tersebut akan menimbulkan kesulitan besar dan bahkan cenderung kontraproduktif ketika dipaksakan untuk diadopsi secara penuh ke dalam masyarakat muslim, hal ini disebabkan adanya perbedaan mendasar yang membentuk bangunan kemasyarakatan dari masing-masing peradaban. Pendekatan Islam haruslah jelas-jelas bersifat ideologis dan berorientasi pada nilai-nilainya. Konsep pembangunan ekonomi senantiasa terikat oleh kondisi budaya, sosial dan politik setempat. Sistem ekonomi Islam mempunyai pengertian khusus dan unik. Beberapa aspek pembangunan sistem ekonomi, seperti keadilan sosial dan hak asasi (social justice and human rights), mempunyai persamaan dengan konsep Barat, meskipun banyak perbedaan dan memiliki dasar pokoknya yang berbeda.

Singkatnya, dari diskusi di atas kiranya menjadi relevan bagi kita untuk mengkaji pandangan Islam untuk memecahkan persoalan ekonomi. Ini bermuara pada pengkajian konsep-konsep dasar Ilmu Ekonomi Islam untuk melakukan transformasi ekonomi masyarakat, khususnya masyarakat 
muslim. Harus diakui bahwa proyek Islamisasi ekonomi telah menjadi obor terdepan bagi pengembangan sistem ekonomi Islam. Bahkan para penggiat perbankan dan keuangan Islam juga telah berhasil merintis terwujudnya sistem keuangan Islam secara global dan diakui eksistensinya dalam percaturan ekonomi di Dunia saat ini, terlepas dari pro dan kontra yang menyertainya.

Sebagaimana ditegaskan di atas, keberadaan sistem ekonomi Islam merupakan konsekuensi dari pandangan hidup Islam (Islamic worldview). Worldview Islam yang menjadi dasar ini oleh para Ulama dan Cendekiawan muslim disebut dengan berbagai istilah; Maulana al-Maududi mengistilahkannya dengan Islami nazariat (Islamic Vision), Sayyid Qutb menggunakan istilah al-Tasawwur al-Islami (Islamic Vision), Mohammad Atif al-Zayn menyebutnya al-Mabda' al-Islami (Islamic Principle), sedangkan Naquib al-Attas menyebutnya dengan Ru'yatul Islam lil Wujud (dalam Zarkasyi, 2005: 11).

Meskipun secara istilah terjadi perbedaan penyebutan, tetapi secara esensi terdapat kesamaan keyakinan para cendekiawan tersebut bahwa pandangan hidup (worldview) seorang muslim haruslah menjadikan Islam sebagai sistem hidup yang mengatur semua sisi kehidupan manusia, yang menjanjikan kesejahteraan dan keselamatan dunia dan akherat. Worldview ini lahir dari adanya konsep-konsep Islam yang mengkristal menjadi kerangka berfikir (mental framework). Islam pada hakekatnya merupakan panduan pokok bagi manusia untuk hidup dan kehidupannya, baik itu aktifitas ekonomi, politik, hukum maupun sosial budaya. Islam memiliki kaidahkaidah, prinsip-prinsip atau bahkan beberapa aturan spesifik dalam pengaturan detil hidup dan kehidupan manusia. Islam mengatur hidup manusia dengan kefitrahannya sebagai individu (hamba Allah SWT) dan menjaga keharmonian interaksinya dalam kehidupan sosial-kemasyarakatan. Dalam aktifitas kehidupan manusia, beberapa aspek aktifitas tersebut memiliki sistemnya sendiri-sendiri, misalnya aspek ekonomi, hukum, politik dan sosial budaya. Dan Islam yang diyakini sebagai sistem yang terpadu dan menyeluruh tentu memiliki formulasinya sendiri dalam aspek-aspek tersebut. Sistem ekonomi Islam, sistem hukum Islam, sistem politik Islam dan sistem sosial-budaya Islam merupakan bentuk sistem yang spesifik dari konsep Islam sebagai sistem kehidupan (Sakti, 2003: 16. Secara garis besar, 
aspek-aspek sistem ekonomi yang dibangun dari worldview Islam akan dikemukakan berikut ini.

\section{Aspek Kepemilikan}

Dalam pandangan Islam, pemilik mutlak dari seluruh alam semesta ini adalah Allah (Q.S. Al-Maidah (5):17-18), dalam hal ini manusia merupakan khalifah Allah yang mengemban amanatNya (Q.S. Al-Baqarah (2):30). Tiaptiap individu bertanggung jawab secara langsung kepada Tuhannya atas segala tindakannya (Q.S. Yasin (36):54). Ini mengandung pengertian bahwa di satu sisi, Allah memberi kekuasaan kepada manusia untuk memiliki dan mengolah apa saja yang ada di bumi, dan di sisi lain manusia harus menyadari statusnya sebagai pengemban amanat. Oleh karena itu, Islam hanya mengabsahkan kepemilikan yang bermula dari proses yang sah (Al-Nabahan, 2000: 43).

Proses atau cara perolehan kepemilikan yang sah ini oleh Haider Naqvi (2003: 146) diartikan sebagai upaya atau kerja seseorang untuk mendapatkan hasil. Ia mencontohkan, implikasi dari prinsip ini adalah bahwa penguasaan pribadi atas lahan yang tidak ditanami sendiri (tidak dimanfaatkan) adalah tidak dibenarkan dalam Islam. Lebih jauh, ia menilai bahwa struktur feodal kepemilikan lahan yang umum dimiliki kebanyakan negara-negara muslim adalah bertentangan dengan semangat hukum Islam. Dalam hal ini, reformasi struktur kepemilikan lahan merupakan bagian penting dari program penghapusan kemiskinan.

Islam tidak menganjurkan kesamaan ekonomi, tetapi mendukung dan mendorong kesamaan sosial sehingga sampai tahap bahwa kekayaan negara yang dimiliki tidak hanya dinikmati oleh sekelompok tertentu saja. Di samping itu, sangat penting setiap individu dalam sebuah negara mempunyai peluang yang sama untuk berusaha mendapatkan pekerjaan atau menjalankan berbagai aktifitas ekonomi (Rahman, 1995: 8-10).

Salah satu karakteristik ekonomi Islam mengenai kepemilikan harta yang tidak terdapat dalam perekonomian lain adalah Zakat. Sistem perekonomian diluar Islam tidak mengenal tuntutan Allah kepada pemilik harta, agar menyisihkan sebagian harta tertentu sebagai pembersih jiwa dari sifat kikir, dengki, dan dendam. Jika dalam ekonomi konvensional pemerintah 
memperoleh pendapatan dari sumber pajak, bea cukai dan pungutan, maka Islam memberi penekanan khusus pada zakat. Kepemilikan invdividu dalam Islam, dengan demikian, selalu dikaitkan dengan kesejahteraan masyarakat. Di sisi lain, pengakuan terhadap kecenderungan manusia untuk memiliki harta ini akan menjadi motivasi dan memungkinkan mereka untuk memanfaatkan sumber daya secara optimal.

\section{Aspek Insentif Ekonomi}

Kapitalisme merupakan salah satu wujud implemetasi kegiatan ekonomi yang digerakkan oleh motivasi individual. Bila seseorang meyakini bahwa harta miliknya adalah diperoleh dari usahanya sendiri, maka ia dapat menggunakannya sesuai dengan kehendaknya. Oleh karena itu, pengejaran materi merupakan standar rasionalitas dalam definisi ilmu ekonomi kapitalis, yang oleh Adam Smith dan kemudian dilanjutkan oleh Alfred Marshall diformulasikan sebagai the wealth (kesejahteraan). Sebaliknya, dalam sistem ekonomi sosialis kegiatan ekonomi lebih didorong oleh insentif keamanan dan kenyamanan sosial. Meskipun kedua ekstrim sistem ekonomi tersebut didasarkan pada insentif yang berbeda, namun baik insentif individu maupun insentif sosial sama-sama mengukur kesejahteraan dengan aspek materiil.

Sebagai konsekuensi dari insentif tersebut, kesejahteraan individu (kapitalis) dimaknai dengan tingginya pendapatan dan daya beli individu, sedangkan kesejahteraan sosial (sosialis) seringkali dimaknai dengan tingginya pendapatan dan daya beli masyarakat. Sekali lagi, rasionalitas kedua insentif itu pada akhirnya menuntut pemaksimalan keinginan akan kepuasan material sebagai tujuan yang harus dicapai. Inilah yang menjadi fondasi ilmu ekonomi konvensional, dari aliran klasik sampai sekarang. Dalam penilaian Durkheim, sebagaimana dituturkan Budiman (1997: 57), konsekuensi logis dari dipraktikkannya pabrikasi kapitalisme telah menggerogoti tatanan sosial tradisional yang sebetulnya sarat dengan nilai solidaritas dan persaudaraan.

Islam mengakui motivasi dan insentif materiil maupun non-materiil bagi setiap individu. Dengan demikian, setiap kegiatan ekonomi dapat dikaitkan dengan insentif yang akan dirasakan di dunia maupun yang akan dirasakan di Hari Kemudian. Kedua insentif ini sejalan dengan tujuan syariah itu sendiri, yaitu mewujudkan kemashlahatan. 


\section{Aspek Mekanisme Pengambilan Keputusan}

Secara garis besar, mekanisme pengambilan keputusan dapat dibedakan menjadi dua kutub; sentralisasi (planned economy) dan desentralisasi (Carson, 1990: 27). Dalam sistem ekonomi planned, pemerintah menentukan rencana strategi pertumbuhan ekonomi negara. Ini berarti bahwa negara menformulasikan dan mengimplementasikan seperangkat prioritas rencana selama jangka waktu tertentu yang dapat mempengaruhi komposisi produksi barang dan jasa jenis-jenis input yang digunakan dalam produksi.

Ekonomi Islam tidak manfikan intervensi pemerintah. Campur tangan pemerintah merupakan sebuah keniscayaan ketika perekonomian dalam kondisi darurat, selama hal ini dibenarkan secara syara'. Pada sisi lain kepemilikan dan kebebasan individu dibenarkan sepanjang tetap pada koridor syariah. Kebebasan tersebut akan mendorong masyarakat untuk beramal dan berproduksi demi tercapainya kemaslahatan hidup bermasyarakat.

Ekonomi Islam memandang bahwa individu, masyarakat serta pemerintah memiliki peran sendiri-sendiri sehingga sistem penerapan sentralistik maupun desentralistik semata tidak akan mampu memenuhi kebutuhan individu dan sosial. Dalam hal-hal tertentu, misalnya untuk menetapkan harga input maupun output, dibutuhkan model pengambilan keputusan desentralistik. Dalam aspek lainnya, misalnya ketika prinsip keadilan sangat dominan, maka prinsip sentralistik berbasis syariah perlu diterapkan, misalnya dalam hal distribusi barang publik dan kesejahteraan dan penegakan kebenaran.

Kemaslahatan dari individu dan masyarakat merupakan hal terpenting dalam kehidupan ekonomi. Hal inilah yang menjadi karakteristik ekonomi Islam, dimana kemaslahatan individu dan bersama harus saling mendukung dan didikotomikan. Dalam arti, kemaslahatan individu tidak boleh dikorbankan demi kemaslahatan bersama dan sebaliknya. Dalam mewujudkan kemaslahatan kehidupan bersama, negara mempunyai hak intervensi apabila terjadi eksploitasi atau kezaliman dalam mewujudkan sebuah kemaslahatan. Negara harus bertindak jika terjadi penyimpangan operasional yang merugikan hak-hak kemaslahatan. Untuk mengatur dan menjaga kemaslahatan masyarakat, diperlukan sebuah instansi yang mendukung. Al-Hisbah merupakan instansi keuangan dalam pemerintahan Islam masa awal yang berfungsi 
sebagai pengawas atas segala kegiatan ekonomi. Lembaga tersebut bertugas mengawasi semua infrastruktur yang terlibat dalam mekanisme pasar. Apabila dalam mekanisme terjadi penyimpangan operasional, maka Al-Hisbah berhak melakukan intervensi. Selain itu, Al-Hisbah mempunyai wewenang untuk mengatur tata letak kegiatan ekonomi, disamping diwajibkan untuk menyediakan semua fasilitas kegiatan ekonomi demi terciptanya kemaslahatan bersama.

\section{Aspek Mekanisme Koordinasi}

Kekuatan penggerak utama Ekonomi Islam adalah kerjasama. Seorang muslim, apakah ia sebagai pembeli, penjual, penerima upah, pembuat keuntungan dan sebagainya, harus berpegang pada tuntunan agama. Kepemilikan kekayaan pribadi harus berperan sebagai kapital produktif yang akan meningkatkan besaran produk nasional dan meningkatkan kesejahteraan masyarakat. Al Qur' an menegaskan, “...supaya harta itu jangan hanya beredar di kalangan orang-orang kaya saja di antara kamu...' (QS 57:7). Oleh karena itu, sistem ekonomi islam menolak terjadinya akumulasi kekayaan yang dikuasai oleh beberapa orang saja. Konsep ini berlawanan dengan sistem kapitalis, di mana kepemilikan industri didominasi oleh monopoli dan oligopoli, tidak terkecuali industri yang merupakan kepentingan umum.

Islam menjamin kepemilikan masyarakat dan penggunaannya direncanakan untuk kepentingan orang banyak. Para ulama banyak merujukkan prinsip ini pada hadits yang menyatakan bahwa, "Masyarakat punya hak yang sama atas air, padang rumput dan api" (Al Hadits). Sabda Rasulullah tersebut menghendaki semua industri ekstraktif yang ada hubungannya dengan produksi air, bahan tambang, bahkan bahan makanan harus dikelola oleh negara. Demikian juga berbagai macam bahan bakar untuk keperluan dalam negeri dan industri tidak boleh dikuasai oleh individu.

Peranan negara, dalam sistem ekonomi Islam tidak dapat disamakan dengan bentuk "campur tangan" yang mengarah kepada kapitalisme laissez faire. Demikian juga, tidak dalam bentuk kolektivisme dan regimentasi yang menindas kebebasan dan melemahkan motivasi dan usaha individu (Chapra, 1992: 223). Islam berupaya menggabungkan inisiatif pribadi dengan intervensi pemerintah agar dapat mencapai "keseimbangan sosial" (Naqvi, 2003: 94). 
Peranan utama negara, dengan demikian adalah dalam mengupayakan restrukturisasi hak-hak properti pribadi serta dalam menjamin standar hidup minimum terhadap kalangan yang kurang beruntung dalam masyarakat.

\section{Penut up}

Tinjauan inter-sistemik dalam tulisan ini menunjukkan bahwa sistem ekonomi Islam ditentukan berdasarkan parameter-parameter sistem etisnya sendiri, di mana kadang-kadang menunjukkan adanya orisinalitas dan relativitasnya. Tidak seperti sistem lain, impuls-impuls etik yang didasarkan pada worldview Islam tersebut sepenuhnya terintegrasi dengan motif-motif ekonomi Islam. Kebebasan terbatas yang ditetapkan untuk perilaku konsumsi dan produksi, serta penekanan pada distribusi kekayaan tidak dapat dipisahkan dari tujuan kemaslahatan (dunia maupun akhirat). Bila epistemologi ekonomi Islam ini dipahami, maka tidak akan ada kerancuan dengan sistemsistem ekonomi lain.

\section{Daftar pustaka}

Ahmad, Khursid, "Pembangunan Ekonomi dalam Perspektif Islam", dalam Ainur R. Sophian (Ed), "Etika Ekonomi Politik; Elemen-elemen Strategis Pembangunan Masyarakat Islam”, Surabaya: Risalah Gusti, 1997.

Barth, James R., and Gerard Caprio, Jr. China's Changing Financial System: Can It Catch Up With, or Even Drive Growth. Networks Financial Institute.,2007.

Brabant, Jozef M. von, The Planned Economies and International Economic Organizations, Cambridge University Press, 1991

Bertell, Ollman,. Market Socialism: The Debate Among Socialists, UK: Routledge , 1997.

Budiman, Hikmat, Pembunuhan yang Selalu Gagal: Modernisasi dan Krisis Rasionalitas menurut Daniel Bell, Yogayakarta: Pustaka Pelajar, 1997.

Carson, Richard L., Comparative Economic Systems, New York: M.E. Sharpe, Inc., 1990.

Chapra M. Umer, Islam and the Economic Challenge, USA: The International Institute of Islamic Thought, 1992. 
, What is Islamic Economics?, Saudi Arabia: Islamic Research and Training Institute, 1996.

Danny, Myers, Construction Economics, UK: Spon Press, 2004.

Ebenstein, W., Isme-Isme Dewasa Ini, Jakarta: Erlangga, 1990.

Friedman, Milton, Capitalism and Freedom, California: The University of Chicago, 1972.

Lerner, Robert E., Western Civilization, New York-London: Norton \& Company, 1988.

Mannan, M. A., Islamic Economics as a Social Science: Some Methodological Issues, Cambridge: The Islamic Academy, 1986.

Murchland, Bernard, Humanisme dan Kapitalisme, Yogyakarta: Tiara Wacana, 1992.

Nabahan, M. Faruq al-, Al-Iqtishad al-Islami, terj. Muhadi Z. dan A. B. Noersalim Yogyakarta: UII Press, 2000.

Naqvi, Syed Nawab Haider, Islam, Economics, and Society, terj. M. S. Anam dan M. Ufuqul Mubin Yogyakarta: Pustaka Pelajar, 2003. , Ethics and Economics: An Islamic Synthesis, UK: The Islamic Foundation, 1981.

Rahman, Afzalur Economic Doctrines of Islam, terj. Soeroyo dan Nastangin, Yogyakarta: PT. Dana Bhakti Wakaf, 1995.

Rand, Ayn, Capitalism: The Unknown Ideal, New York: A Signet Book, 1970.

Wright, Robert, The Moral Animal, New York: Vintage Books, 1994.

Sakti, Ali, "Pengantar Ekonomi Islam”, Jakarta: Modul Kuliah STEI SEBI, 2003.

Zarkasyi, Hamid Fahmy, "Worldview Sebagai Asas Epistemologi Islam", dalam Islamia Tahun II No. 5, April-Juni 2005. 